\title{
Diversification of the Nigerian Economy towards a Sustainable Growth and Economic Development
}

\author{
Suberu O. J., Ajala O. A., Akande M. O., Olure-Bank Adeyinka \\ Department of Banking and Finance, The Polytechnic Ibadan, U.I Post office Box, Ibadan, Oyo State, Nigeria \\ Email address: \\ un_va@yahoo.com (Suberu O.J.)
}

\section{To cite this article:}

Suberu O. J., Ajala O. A., Akande M. O., Olure-Bank Adeyinka. Diversification of the Nigerian Economy towards a Sustainable Growth and Economic Development. International Journal of Economics, Finance and Management Sciences. Vol. 3, No. 2, 2015 , pp. 107-114. doi: 10.11648/j.ijefm.20150302.15

\begin{abstract}
As a matter of priority, Nigeria government must encourage the diversification of Nigeria's economy. It is the only viable way to survive the current environment of global economic uncertainty with the volatility of oil price. It is crucial that government do not believe that oil provides an endless source of revenue. Nigerian economy is mono-economy, depending on oil. Good percentage of Nigerians live in abject poverty, unemployment is on the high and productivity is at its lowest level. Given this, the study seeks possible ways of diversifying the productive base of the Nigerian economy. Using descriptive method of analysis, it is revealed that considering Nigeria's peculiar circumstances and the successes recorded before the advent of oil, for Nigeria to break loose from the problems inherent in a mono-economy, especially one largely dominated by oil, which is subject to depletion, international price shocks and unfavorable quota arrangement, there is need for diversification. Agricultural sector is suggested as possible options for diversifying the Nigerian economy. Drawing from the implications of the study, certain recommendations, which include among others, that the one sector must not be sustained by foreign innovation and technology. The only sensible and durable way to sustain the economy is Nigerian innovation. The first section examines a general background of study and set out the significance objectives of the study. It also highlights the methodology to be employed to address the key issues. The second section, gives the outlook of the Nigerian economy with a view to examining the need for diversification of the economy towards agriculture and solid mineral development. Section three will be a brief review of the Nigerian agriculture development policies. Section four examines the impact of the contribution of the agriculture sector to the economic development of the Nigeria. Section five will focus on the opportunities and potentials for agriculture development in Nigeria as well as the value addition chain.
\end{abstract}

Keywords: Nigeria, Oil, Diversification, Agriculture

\section{Introduction}

Nigeria is largest oil exporting country in Africa and has a rapidly growing economy. The country follows a resource based growth strategy driven by the production and exporting of oil. With the volatility of global oil prices and often volatile growth of Nigeria's economy, the country has wasted much of its opportunities to break away from underdevelopment despite its massive natural and human resources endowments. It has dwelled only on its huge crude oil resources as the major source of revenue, driving a monolithic economy for years in spite of the enormous developmental challenges it faces. Regrettably, the oil resources are being mismanaged and a substantial part of it has gone on rent seeking and red-tapism common in Nigerian bureaucracy. For more than a decade now, Nigeria has been enjoying high levels of economic growth, human development, and relative political stability. As it continues along the path of economic progress, it is imperative that the country finds ways to diversify its economy by boosting nontraditional sectors, expanding its range of products for exports and engaging new economic and trade partners. The economic nerve centre of Africa shifted northward this year when Nigeria took South Africa's long-held position as the country with the continent's largest Gross Domestic Product (GDP). While GDP neither reflects the wealth distribution nor accounts for the size of the population, it is a significant indication of Nigeria's emerging economic power. If these 
growing resources are invested intelligently, the country can benefit and exceed the International Money Fund's estimated GDP growth of seven per cent this year. As a matter of priority, Nigeria government must encourage the diversification of Nigeria's economy. It is the only viable way to survive the current environment of global economic uncertainty with the volatility of oil price. It is crucial that government do not believe that oil provides an endless source of revenue

At the advent of democracy in 1999, Obasanjo's first full national budget in 2000 was under N600bn naira but now we have as much as $800 \%$ increase over this, yet we can only see little development but surplus of preaching's and governance by billboards while vision $20-2020$ is in a state of rest like Newton's first law of thermodynamics. We say unequivocally that resource looting and wastage is much concentrated at the state levels, because most of our Governors are not just most wanting but problematic and the very impediment to development.

Diversification presents the most competitive and strategic option for Nigeria in light of her developmental challenges and given her background. Diversification has a lot of benefits for Nigeria to maximally utilize her abundant resource - base to rebuild the economy and enjoy the benefits of all the linkages, synergy, economies of scale, grow national technology and foreign investment profile, build human capital, exploit new opportunities, lessen averagely operational costs, increase national competitiveness and grow the standard of living and confidence of the citizens for national renaissance.

Diversification does not occur in a vacuum. And, the need to have in place an enabling environment to make diversification possible remains necessary. A number of key drivers have already been identified. These, for example, include investment, trade and industrial policies; a dynamic growth performance; macroeconomic stability; a competitive exchange rate and expansionary but responsible fiscal policy as well as institutional variables such as good governance and absence of conflict and corruption.

\section{Nigeria Economic Outlook}

Nigeria is a middle income, mixed economy and emerging market, with expanding financial service, communications technology and entertainment sectors. It is ranked 26th in the world in terms of GDP (nominal: 30th in 2013 before rebasing, 40th in 2005, 52nd in 2000), and is the largest economy in Africa (based on rebased figures announced in April 2014). It is also on track to become one of the 20 largest economies in the world by 2020. Its re-emergent, though currently underperforming, manufacturing sector is the third-largest on the continent, and produces a large proportion of goods and services for the West African region. Nigeria recently changed its economic analysis to account for rapidly growing contributors to its GDP, such as telecommunications, banking, and its film industry. As a result of this statistical revision, Nigeria has added $89 \%$ to its
GDP, making it the largest African economy. (Wikipedia, the free encyclopedia)

Nigeria rebased its GDP from 1990 to 2010, resulting in an $89 \%$ increase in the estimated size of the economy. As a result, the country now boasts of having the largest economy in Africa with an estimated nominal GDP of USD 510 billion, surpassing South Africa's USD 352 billion. The exercise also reveals a more diversified economy than previously thought. Nigeria has maintained its impressive growth over the past decade with a record estimated $7.4 \%$ growth of real gross domestic product (GDP) in 2013, up from $6.7 \%$ in 2012. This growth rate is higher than the West African sub regional level and far higher than the sub-Saharan Africa level (African Economic Outlook (AEO) 2014)

The 1970's ushered Nigeria into a new era of prosperity, enjoying a bounteous oil windfall due to the increase in global oil prices precipitated by the Arab Israeli crisis. The negative effects of this oil windfall were reflected in exchange rate appreciation, import subsidies, and a decline in vital sectors such as Agriculture and manufacturing in the case of Nigeria, the solid mineral sector also suffered as earlier pointed out. However, the profligacy and waste that accompanied Nigeria's elevation to the status of an oil-rich petro state experienced a hitch at the start of the next decade. The 1980's oil glut forced a sharp drop in oil receipts, and consequently economic growth. Confronted with corruption, capital flight and mounting foreign debt, Nigeria, was left with no option but to undergo structural reforms such as the IMF's Structural Adjustment Programme (SAP) to address the distortions caused by oil dependence. With the return to democratic rule in 1999, a series of macroeconomic and fiscal reforms have been undertaken, most of them having economic diversification as a core element. It was also able to secure a debt buy back deal from the Paris club in 2006 which reduced the external debt even though her current domestic debt of circa $\$ 34$ billion is a threshold that is perturbing (Olumide .S. Ayodele, et al,2013.)

The President said during an interview with China Television in Beijing that the increasing utilization of shale gas and other alternative sources of energy by the United States and other advanced oil importing nations of the world was a matter of concern for Nigeria. "That is why we have to increase the pace of diversifying our economy and move our country away from dependence on the oil and gas industry," the president said. "We must work towards greater industrialization; add more value to our agricultural products; develop our solid minerals potentials and other sectors of our economy before the time comes when crude oil may no longer be dominant as a global source of energy."

Diversification implies "movement into new fields and stimulation and expansion of existing traditional products." Diversification does not discourage specialization, but requires that resources be channeled into the best alternative uses (Ayeni, 1987; Iniodu, 1995).

In macroeconomic planning, diversification promotes growth and development through the mobilization of savings from surplus sectors for use in the development of deficit 
sectors of the economy. Options for diversifying an economy abound, such as agriculture, entertainment, financial services, industrialization, information and communication technology, tourism, mining, etc. However, it is worthy to note that country-specific circumstances ought to as a matter of necessity, be considered. This is cogent, since due to structural differences, a model that fits an economy perfectly well may prove irrelevant in another. With a major objective of diversifying the productive base of the Nigerian economy with a view to reducing dependence on the oil sector, this study zero in on 'agriculture' and 'mining,' as imperatives. The choice of this dual approach is informed by Developmental Policy in Nigeria and the huge successes recorded by some Asian countries-which are collectively referred to as 'Asian Tigers'-in applying these imperatives, as well as the fact that these countries were basically at the same level of national development with Nigeria, at the time of their respective take-off and still share certain similarities with Nigeria. The effects of diversification in an economy
(Sunday A. Eko, et al. 2013)

The schema below paints a picture of possible impacts of diversification on an economy. It is explicit as shown in panel A that dependence on a single commodity, for instance, oil, in the case of Nigeria, the economy is prone to both internal and external shocks, which ultimately result in structural defects.

As posited by Ayeni (op. cit.), the reason for such defects is anchored on the fact that in the event of any deficit, there will be no other sector(s) to mobilize surpluses for use by the deficit sector(s). Given the shift (total or partial)-but in most cases partial, away from a single item to other sectors of the economy (i.e. agriculture and mining) as reflected in panel B, the economy tends to be insulated from shocks. Assuredly, the economy becomes devoid of structural defects and ceteris paribus, this brings about an appreciable level of progress. An in-depth analysis of the two sectors heretofore mentioned is presented in the ensuing sections.
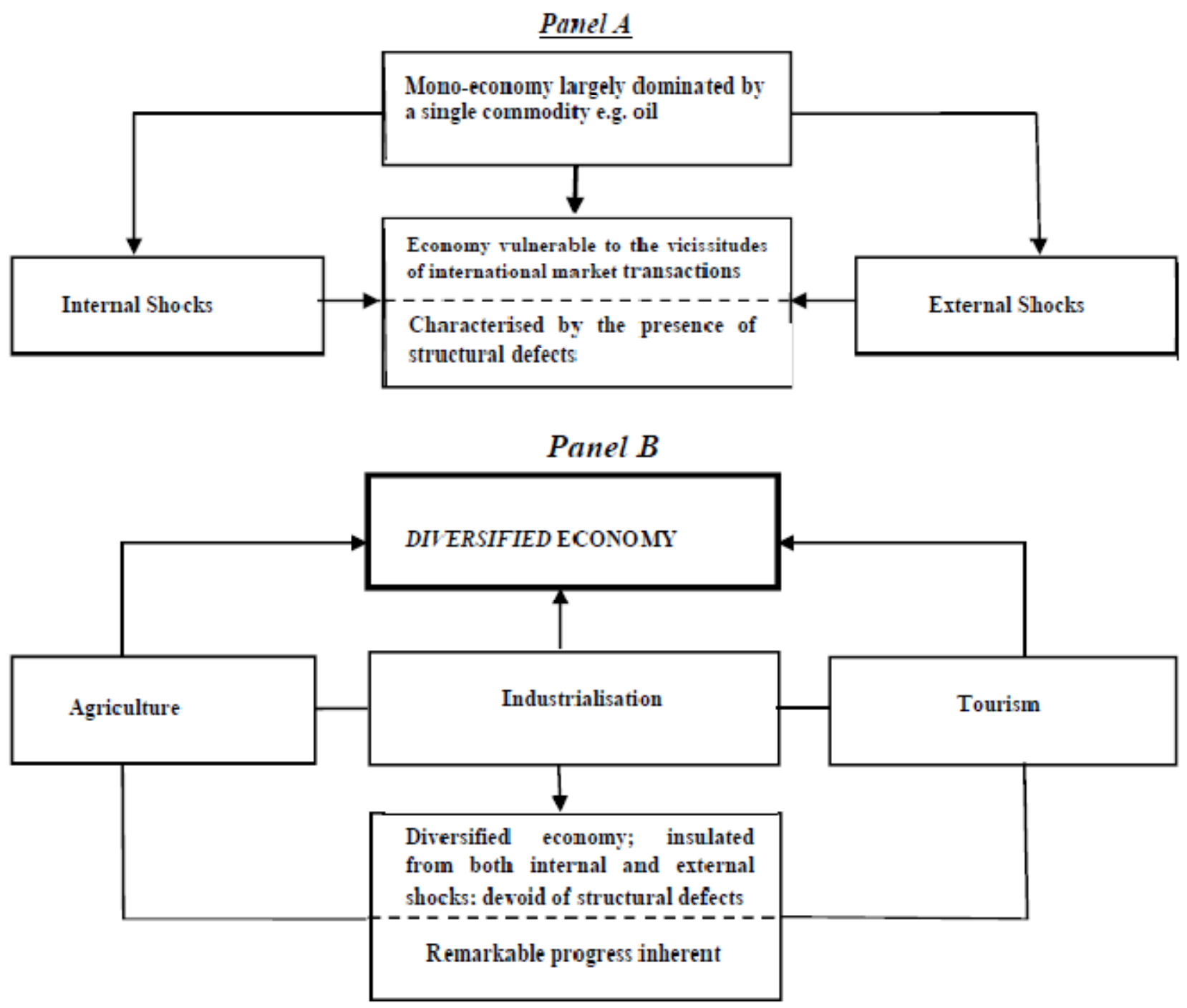

Figure 1. Schema showing the effects of diversification on an economy. 


\section{A Critical Review of the Nigerian Agriculture Development Policy}

Agriculture has suffered from years of mismanagement, inconsistent and poorly conceived government policies, neglect and the lack of basic infrastructure. Still, the sector accounts for over $26.8 \%$ of GDP and two-thirds of employment. Nigeria has 19 million head of cattle, the largest in Africa. Nigeria is no longer a major exporter of cocoa, groundnuts (peanuts), rubber, and palm oil. Cocoa production, mostly from obsolete varieties and overage trees, has nevertheless increased from around 180,000 tons annually to 350,000 tons.

A dramatic decline in groundnut and palm oil production also has taken place. Once the biggest poultry producer in Africa, corporate poultry output has been slashed from 40 million birds annually to about 18 million. Import constraints limit the availability of many agricultural and food processing inputs for poultry and other sectors. Fisheries are poorly managed. Most critical for the country's future, Nigeria's land tenure system does not encourage long-term investment in technology or modern production methods and does not inspire the availability of rural credit.

Agricultural products include cassava (tapioca), corn, cocoa, millet, palm oil, peanuts, rice, rubber, sorghum, and yams. In 2003 livestock production, in order of metric tonnage, featured eggs, milk, beef and veal, poultry, and pork, respectively. In the same year, the total fishing catch was 505.8 metric tons. Round wood removals totaled slightly less than 70 million cubic meters, and sawn wood production was estimated at 2 million cubic meters. The agricultural sector suffers from extremely low productivity, reflecting reliance on antiquated methods. Although overall agricultural production rose by $28 \%$ during the 1990 s, per capita output rose by only $8.5 \%$ during the same decade. Agriculture has failed to keep pace with Nigeria's rapid population growth, so that the country, which once exported food, now relies on imports to sustain itself

\subsection{Agriculture}

Agriculture involves the cultivation of land, raising and rearing of animals for providing food for human consumption, raw materials for industries and feed for animals. It is composed of crop production, livestock, forestry and fishing. Agriculture was the mainstay of Nigeria up to the period oil was discovered in commercial quantity, with the first export dating back to the 16th century when James Watt and his crew shipped 32 barrels of palm oil along with 150 elephant tusks and 589 sacks of pepper from Nigeria to England (NTJ, 1967:53).

The place of agriculture in Nigeria's economy has remained critical over the decades. Prior to the political crisis of 1967-1970, agriculture's positive contributions to the economy were instrumental in sustaining economic growth and stability. The bulk of food demand was satisfied from domestic output, thereby obviating the need to utilize scarce foreign exchange resources on food importation. Stable growth in agricultural exports constituted the backbone of a favorable balance of trade. Sustainable amounts of capital were derived from the agricultural sector through the imposition of several taxes and accumulation of marketing surpluses, which were used to finance many development projects. A typical example is the first Nigerian skyscraper the cocoa house in Ibadan, which was built with proceeds from the sale of cocoa. However, the crisis that developed in Nigerian economy during the civil war became more serious in the early 1970 s, which coincided with the rising fortunes of the petroleum sector. From that period to date, agriculture's contributions to the economy became relatively insignificant. This development is reflected in rising food prices and inflation, increased imports of food and agricultural raw materials for local industries, a relative decline in agricultural export earnings and deteriorating living conditions in the rural areas. The sector, which employed $71 \%$ of the total labor force in 1960 , employed only $56 \%$ in 1977 . The number stood at $68 \%$ in 1980 , falling to $55 \%$ in 1986, 1987 and 1988; and $57 \%$ annually from 1989 to 1992 , and has continued to nosedive until date.

Ojo M.O (1994) classified the problems associated with Nigerian agricultural development into six groups, namely: environment, land, labor, capital, technology, and marketing. The above constraints have implications for agricultural productivity in Nigeria. For instance, they make productivity in the agricultural sector very low. The fundamental problem is thus how to improve productivity.

\subsection{Past Efforts at Revamping Agriculture in Nigeria}

Nigeria's agricultural policy objectives since independence in 1960 have been geared towards: (i) the achievement of increase in productivity; (ii) the achievement of selfsufficiency in food production; (iii) self-sustained growth in agricultural sector; and (iv) the realization of structural transformation.

In pursuance of these policy objectives, government have adopted the following policies and projects

Table 1. Major agricultural policies and projects in Nigeria (1972-Date).

\begin{tabular}{lll}
\hline S/N PROJECT & COMMENCEMENT DATE & AREAS OF EMPHASIS \\
\hline 1 Agricultural Development Projects(ADPs) & 1972 & $\begin{array}{l}\text { Extension, supply of inputs and infrastructure } \\
\text { Emphasis on agriculture research and the establishment } \\
\text { 2. Reorganisation of Agricultural Research Institute Decree }\end{array}$ \\
$\begin{array}{l}\text { Research Institutes Establishment Order National Science and } \\
\text { Technology Development Agency (NSTDA) Decrees1973 }\end{array}$ & 1973 & \\
3. National Accelerated Food Production Project (NAFPP) & 1975 & Food production, supply of inputs and new technology \\
\hline
\end{tabular}




\begin{tabular}{|c|c|c|}
\hline S/N PROJECT & COMMENCEMENT DATE & AREAS OF EMPHASIS \\
\hline & & to farmers \\
\hline 4 Tree Crop Programme & 1975 & Tree Crop Production \\
\hline $\begin{array}{l}5 \text { River Basin Development Authorities (RDBAs) Decree } 25 \\
\text { (Amended 1977,1979) }\end{array}$ & 1976 & $\begin{array}{l}\text { Direct government involvement in agricultural } \\
\text { production activities, provision of water and irrigation } \\
\text { to farmer settlements, supply of fertilisers and others }\end{array}$ \\
\hline 6 Farm Input Subsidies and Fertiliser Subsidy Programme & 1976 & Supply of fertilisers and other inputs \\
\hline 7 Strategic Grains Research Scheme & 1976 & Storage of grains \\
\hline 8 Operation Feed the Nation & 1976 & $\begin{array}{l}\text { Trying to make everybody a farmer (through subsidies } \\
\text { on) fertilisers, livestock products and inputs, fisheries } \\
\text { inputs, seeds, etc., to increase production }\end{array}$ \\
\hline $\begin{array}{l}9 \text { Nigerian Agricultural and Co-operative credit to } \\
\text { Bank(NACB) }\end{array}$ & 1973 & Establishment of guaranteed loans and other farmers \\
\hline The Rural Banking Scheme & 1977 & \\
\hline Agricultural Credit Scheme & 1977 & \\
\hline 10 Commodity Boards Decree & 1977 & $\begin{array}{l}\text { Establishment of commodity marketing boards e.g. } \\
\text { palm products, etc. }\end{array}$ \\
\hline 11 The Green Revolution Programme & 1980 & The nation's food production plan \\
\hline 12. Agricultural Policy Initiative and Reforms & 1986 & \\
\hline $\begin{array}{l}\text { a ,Directorate of Food, Roads and Rural Infrastructure } \\
\text { (DFRRI) }\end{array}$ & 1986 & $\begin{array}{l}\text { Construction and repair of rural roads, provision of } \\
\text { water and electricity to rural communities Reduction in } \\
\text { the number of River Basin Authorities }\end{array}$ \\
\hline b. Streamlining of RBDAs' economic & 1987 & Engagement of small scale farmers \\
\hline c. Agriculture under SAP & 1987 & Reduction of export of commodities \\
\hline $\begin{array}{l}\text { d. Scrapping of Commodity Boards } \\
\text { research and }\end{array}$ & 1988 & Promotion of agricultural education, training \\
\hline $\begin{array}{l}\text { e. Establishment of University of Agriculture Project } \\
\text { (UNAAB, UAM) }\end{array}$ & 1989 & For land clearing and mechanisation \\
\hline $\begin{array}{l}\text { f. National Agricultural Land Development by farmer } \\
\text { Authority (NALDA) }\end{array}$ & 1989 & Promotion and adoption of new technologies \\
\hline g. State-wide Agricultural Development Projects (SADPs) & 1991 & $\begin{array}{l}\text { Encouragement of co-operatives formation and pressure } \\
\text { groups }\end{array}$ \\
\hline $\begin{array}{l}\text { h. Support for Farmers' Associations an the formation of } \\
\text { Federation of Farmers Association of Nigeria (FOFAN) }\end{array}$ & 1992 & $\begin{array}{l}\text { Encouragement of co-operatives formation and pressure } \\
\text { groups }\end{array}$ \\
\hline i. Transfer of Agricultural Research Institutes from Federal & & \\
\hline $\begin{array}{l}\text { Ministry of Science and Technology to the Federal Ministry } \\
\text { of Agriculture }\end{array}$ & 1992 & Government engagement in direct food production \\
\hline $\begin{array}{l}\text { j Withdrawal of fertiliser subsidies } \\
\text { 13. Agricultural Policies under the Obasanjo Administration }\end{array}$ & Mid-1990s & Higher price of fertilizer \\
\hline a. Restoration of fertiliser subsidies at $25 \%$ & & $\begin{array}{l}\text { Encouragement of food production by small and } \\
\text { medium scale farmers }\end{array}$ \\
\hline \multicolumn{3}{|l|}{$\begin{array}{l}\text { b. Establishment of Department of 1999-2002 Fertiliser, FMA } \\
\text { c. Food Security and Poverty Alleviation programme }\end{array}$} \\
\hline 14 Agricultural policies under Vision 20-2020 & 2007 & $\begin{array}{l}\text { Serve as youth employment spinner (especially youths } \\
\text { in rural areas), improving productivity of the } \\
\text { agricultural sector }\end{array}$ \\
\hline
\end{tabular}

Source: Sunday A. Eko, et al. 2013 Adapted from Ndon, B. A. (2002), with no modifications by the author

Vision 20-2020 refers to Nigeria's strategic plan and quest to turn around her long term development challenges by maximally creating and appropriating existing opportunities and potentials inherent in the economy to launch herself into the club of the twenty most industrialized nations of the World by the year 2020 . The plan spans the immediate, short, medium and long term space and measures to reinvent the economy. However, there is little to show that there is a time table to this effect, much less of following it. We have continued in our spending spree, looting, indiscipline and lawlessness as is the modus operandi in our national life

\subsection{Constraints to Implementing Sustainable Agriculture}

National and international agricultural research centers are stepping up their efforts to improve the productivity of subsistence farming. Emerging technologies - such as agro forestry, alley and multiple cropping, improved genetic material, nitrogen-fixing trees and crops, and biotechnology - hold much promise. New farming systems are more likely to succeed if they accommodate the existing variability in soils. Several constraints often lead developing countries to resist adopting the concepts and practices of sustainable agriculture.

The overriding constraint may be the absence of economic incentives from the government policymaking level to that of the farmer. Reductions in soil loss or long-term environmental degradation are not tangible inducements for small farmers to adopt sustainable agriculture practices when their immediate concern is simply feeding their families. There are, however, exceptions. A good example is the success of social forestry in India. But even there, farmers' contributions are secondary to their family concerns. 
A second constraint is lack of awareness, not only at the farm level but also at higher levels in the society. Even if the farmers are willing and able, extension services are poor or nonexistent in most developing countries.

A third major constraint is that no system becomes operational if it is not institutionalized. In many developing countries, particularly in Africa, research and development in agriculture are inadequate and suffer from lack of trained personnel, facilities, and motivation. In many African countries, donor-supported research is still the rule. In this situation, it is difficult for a country to build satisfactory research traditions and local expertise; consequently, the benefits are limited to individual projects.

A fourth constraint relates to the information base. Implementing sustainable agriculture assumes that (1) reasons for non sustainability are known, (2) there is sufficient information on the resource base to target activities that will foster sustainability, and (3) the resource base can be monitored to evaluate sustainability. In practically all developing countries, these three conditions are uncertain.

In the past three decades or more, international donor support for agricultural research and development focused on improving the genetic potential of crops and related management practices to improve yields - a spinoff of the Green Revolution. Few developing countries have a systematic, detailed soil resource inventory program. Agronomic research programs, including those by western expatriates, have been conducted and are still being conducted on soils about which little is known. In the absence of information on the resource base, it is usually a waste of time and effort to try to institute sustainable agriculture.

A fifth constraint to implementing sustainable agriculture is that appropriate research methodology is not readily available in developing countries. Until recently, not even the basic principles and concepts had been enunciated. Fundamental questions - such as how long should an experiment be conducted, what are the treatments, what are the measurements, and how can the data be analyzed are yet to be answered.

\section{The Role of Agriculture in the Economic Development of Nigeria}

The traditional approach to the role of agriculture in economic development is formulated in terms of the contributions the agricultural sector can make or the functions it can perform during the process of economic development.

(Anyanwu et al., 1997). As stated by Reynolds (1975), agricultural development can promote the economic development of the underdeveloped countries in four distinct ways by: increasing the supply of food for domestic consumption and releasing the labor force needed for industrial employment; enlarging the size of the domestic market for the manufacturing sector; increasing the supply of domestic savings; and providing the foreign exchange earned by agricultural imports.

According to Omawale and Rogrigues (1979), agriculture has been assigned an important role in national development by most developing countries. It has been seen as a means of reducing dependence on certain importations, containing food price increases, earning foreign exchange, absorbing many new entrants to the labour market and increasing farm incomes at times of severe unemployment and rural poverty.

Agreeing with the above views, Johnston (1970) submitted that the appraisal of agriculture's contribution or role in the national economy can be made using four criteria, namely: the proportion of the population engaged in agriculture; the share of agriculture in the Gross Domestic Product (GDP); the proportion of the nation's resources (other than labour) devoted to or employed in agricultural production; and the contribution of the agricultural sector to foreign trade. The ensuing section appraises some agriculture parameters as reflected in their contribution to the overall development of the Nigerian economy.

\subsection{Agriculture and Employment}

A World Bank Report (1970) puts it that the agricultural sector employed $71 \%$ of the total labor force in Nigeria in 1960. By 1977 , this had dropped to $56 \%$. It increased to $68 \%$ in 1980 , before falling to $55 \%$ in $1985,53 \%$ in $1986,55 \%$ in 1987 and 1988 , and $57 \%$ annually from 1989 to 1992 . This downward trend has continued into the 2000s. The fall in the labor force has been due to structural changes in the economy where other sectors are assuming different dimensions and engaging more labor than they previously did. It is necessary to point out that given the importance of labor in agriculture of most African countries including Nigeria, and the poor labor absorptive capacity of their industrial sector, rapid outflow of labor from the agricultural sector has generated not only social but economic problems as well. A partial consequence of high labor outflow, especially the youth labour force, which Essien (2008) refers to, as "the life-wire of agriculture" from agriculture, has been a decline of agricultural production in Nigeria in recent years. Enhancement of agriculture labour productivity should therefore be a goal for the country.

\subsection{Agriculture and Gross Domestic Product (GDP)}

Table 1 shows the contributions of agriculture to GDP of Nigeria between 1960 and 2010. One of the dogmas of economic development-" "that there is a secular decline of agriculture's share in the GDP in the course of economic development," is manifested here. This is portrayed by the decline in the relative share of agriculture in GDP over the years 
Table 2. Nigeria: contribution of agriculture to GDP [1960-2010 (Nm)].

\begin{tabular}{|c|c|c|c|c|}
\hline Year & Total GDP & $\begin{array}{l}\text { Agriculture as a } \\
\text { Share Of GDP }\end{array}$ & $\begin{array}{l}\text { Share Agriculture as \% } \\
\text { of total GDP }\end{array}$ & $\begin{array}{l}\text { Share Agriculture as a } \\
\% \text { of total GDP }\end{array}$ \\
\hline 1960 & $2,489.0$ & $1,599.8$ & 64.27 & - \\
\hline 1965 & $3,146.8$ & $1,742.2$ & 55.36 & -8.9 \\
\hline 1970 & $4,219.0$ & $1,887.7$ & 44.74 & -10.62 \\
\hline 1975 & $27,172.0$ & $7,639.4$ & 28.11 & -16.63 \\
\hline 1980 & $31,546.8$ & $6,501.8$ & 20.61 & -7.6 \\
\hline 1985 & 201,036 & $65,748.4$ & 32.70 & 12.09 \\
\hline 1990 & $267,550.0$ & 83.344 .6 & 31.15 & -1.55 \\
\hline 1991 & $265,379.1$ & $87,503.5$ & 32.97 & 1.82 \\
\hline 1992 & $271,365.5$ & $89,345.4$ & 32.92 & -0.05 \\
\hline 1993 & $274,833.3$ & $90,596.5$ & 32.96 & 0.04 \\
\hline 1994 & $275,450.6$ & $92,833.0$ & 33.70 & 0.74 \\
\hline 1995 & $281,407.4$ & $96,220.7$ & 34.10 & 0.49 \\
\hline 1996 & $293,745.4$ & $100,216.2$ & 34.12 & -0.07 \\
\hline 1997 & $302,022.5$ & $104,514.0$ & 34.60 & 0.48 \\
\hline 1998 & $310,890.1$ & $108,814.1$ & 35.00 & 0.4 \\
\hline 1999 & $312,183.5$ & $114,570.7$ & 36.70 & 1.7 \\
\hline 2000 & $329,78.7$ & $117,945.1$ & 35.83 & -0.87 \\
\hline 2001 & $356,994.3$ & $122,522.3$ & 34.32 & -1.51 \\
\hline 2002 & $433,203.5$ & $190,133.4$ & 43.89 & 9.57 \\
\hline 2003 & $477,533.0$ & $203,409.9$ & 42.60 & -1.29 \\
\hline 2004 & $527,576.0$ & $216,208.5$ & 40.98 & -1.62 \\
\hline 2005 & $561,931.4$ & $213,463.6$ & 41.19 & 0.21 \\
\hline 2006 & $595,821.6$ & $248,599.0$ & 41.72 & 0.53 \\
\hline 2007 & $634,251.1$ & $266,477.2$ & 42.01 & 0.29 \\
\hline 2008 & $672,202.6$ & $283,175.4$ & 42.13 & 0.12 \\
\hline 2009 & $716,949.7$ & $299,996.4$ & 41.84 & -0.29 \\
\hline 2010 & $775,552.7$ & $316,728.7$ & 40.84 & -1.00 \\
\hline
\end{tabular}

Sources: (1) CBN Statistical Bulletin, Various Issues

(2) National Bureau of Statistics, Various Issues

As reflected on column 4 of table 1 , the percentage share of agriculture to GDP has continued to nosedive starting from 1960 -which has a value of $64.27 \% .1980$ recorded the lowest value of $20.61 \%$. The period 2002 to 2010 recorded some improvements however, with the percentage share of agriculture in total GDP hovering around the $42.05 \%$ mark. The percentage growth rates of agriculture as a share of GDP shown on column 5, further confirms this downward trend. In spite of general decline witnessed during the period, some pockets of improvement as recoded by growth rates can be seen dotted here and there.

\section{Challenges for the Future}

The challenge of enhancing productivity while maintaining environmental soundness and attaining intergenerational equity is enormous for the low-input, resource-poor farmers of developing countries. Sustainable agriculture calls for educating farmers; emphasizing the long-term consequences of their traditional methods of agriculture; and helping them develop and implement innovative, appropriate farming practices. Appropriate incentives are essential.

Without intensified financial and technical assistance, sustainable agriculture in developing countries will be untenable in the immediate future. This essential support could be considered an investment to ensure food security and social stability in the world.

Because sustainable agriculture cannot be achieved overnight, institution building takes on added significance. Many developing countries still do not have detailed information on the resource base; consequently, data bases must be developed and techniques instituted to monitor resources. Likewise, a cadre of highly trained professionals backstopped by adequate facilities is needed to conduct effective resource inventories.

Equally important is the creation of awareness. Private organizations are generally equipped to provide such services but must have funds to carry out their activities.

As the world population increases, additional land will have to be cultivated, and this gives added importance to sustainable agriculture. Major causes of land degradationovergrazing on rangeland, over cultivation of cropland, water logging and salinization of irrigated land, and deforestationall result from poor land management and should, therefore, be able to be controlled.

Although effective technologies that prevent or reduce land degradation either exist or are being developed, their application is still constrained by institutional and societal barriers. Lasting solutions can be rooted as much in social and economic reform as in effective technologies. In the 
Tropics, as elsewhere, the current prospects for institutionalizing development strategies for sustainable agriculture are unique challenges awaiting creative and committed solutions.

\section{Conclusion and Recommendation}

Nigerian government took a bold step with this Agricultural Transformation Agenda (ATA). Of course, many challenges arise when pursuing a diversification strategy. It is often necessary to make significant investments in human resources and infrastructure to support economic sectors and activities such as value-addition in commodities. These are long-term endeavors that need government commitment and political will, not to mention major capital investments. Moreover, in pursuing new sectors, products and partners, Nigerian governments must be careful not to neglect their traditional economic bases. In fact, there are many benefits that could arise from more diversified economies. And, these include less exposure to external shocks, an increase in trade, higher productivity of capital and labor, and better regional economic integration. These benefits, in addition to effective public management, can effectively help reduce poverty and promote human and social development Agriculture is one of the key sectors that provide unrivalled opportunities for Nigeria's accelerated growth. It shares linkage with virtually all the sectors of the economy with proven multiplier effect on the economy. It remains Nigeria's surest most strategic and competitive way to secure her rapid industrialization and future. It creates employment more than any other sector of the economy, earns foreign exchange, provides food and food security, provides raw materials for our plants and industries. It is the basis of the Nigeria economy, and even the source of the much celebrated oil (science of oil formation). From food and cash crops to animal husbandry, horticulture to fishery, the opportunities are numerous (Jeff Okoroafor,2014) The Federal Government's interventions in the agricultural sector, Agricultural Transformation Agenda (ATA) of the present administration has now raised the net earnings of rural farmers to the sum of 174 billion naira due to its activities in five value chains namely Cassava, Rice (Dry Season and Rainy Season), Sorghum, Maize and Cotton, Minister of Agriculture and Rural Development, Dr. Akinwumi Adesina has revealed.

\section{References}

[1] Adubi, A.A. (2004). Agriculture: Its Performance, Problems and Prospects. Centre for Local Government Studies. Ibadan: Jodad Publishers, pp. 192-209.

[2] Anyanwu, J. C. et al. (1997). The Structure of the Nigerian Economy (1960-1997). Onitsha: JOANEE Educational Publishers.
[3] Ayeni, B. (1987). Resource Localisation, Exchange Relations and Diversification of the Nigerian Space Economy. Diversification: Strategy for Nigeria's Economy. Nigerian Economic Society and Heinemann Educational Books (Nigeria), Ibadan, 12-137.

[4] Bayo Durodola, (2014) Nigeria Must Sustain Economy Diversification Policies, CHANNELS TELEVISION African Economic Outlook (AEO) 2014.

[5] CBN. Statistical Bulletin. Various Issues, CBN.

[6] Ekpo, A. H. (2012). Employment, Growth and Poverty Reduction in an Oil Export Economy: Evidence from Nigeria, being paper presented at the 53rd Annual Conference of the Nigerian Economic Society, 27-30 August, Nicon Luxury Hotel, Abuja.

[7] Essien, E. B. (2008). Poverty Reduction in Nigeria: The Role of Rural Agriculture, being a $\mathrm{PhD}$ Workshop paper presented to the Department of Economics, University of Uyo, Nigeria.

[8] Favour Ojiabor (2014) Oil and the Diversification of Nigeria's Economy, This Day Live.

[9] Federal Republic of Nigeria. (2007). Vision 20-2020 Blueprint.

[10] Iniodu, P. U. (1995). Diversifying Nigeria's Non-Export Base for Sustainable Development. External Trade and Economic Development in Nigeria, Selected paper for the 1995 Annual Conference of the Nigerian Economic Society, pp. 277-285.

[11] Jeff Okoroafor , (2014). Diversifying The Nigerian Economy, Pathway To Achieving Economic Stability, Opinion Nigeria, Addressing Today's Topical Issues.

[12] Jonathan E, (2013) Nigeria must urgently diversify her economy from crude oil, Premium Time Wikipedia, the free encyclopedia.

[13] Ndon, B. A. (2002). The Role of Education and Research in Agricultural Development in Nigeria. A Workshop Paper presented at the University of Uyo, p. 34.

[14] Olumide.S. Ayodele, et al.(2013) Economic Diversification in Nigeria: Any Role for Solid Mineral Development? Mediterranean Journal of Social Sciences Published by MCSER-CEMAS-Sapienza University of Rome vol 4 No 6 pp 691-704.

[15] Ojo, M. O. (1994). The Effectiveness of Agricultural Policies on Nigeria's Economic Development. In Ndebbio, J. E.U. and Ekpo, A. H. (Eds.), The Nigerian Economy at the Crossroads: Policies and their Effectiveness. Calabar: University of Calabar Press.

[16] Olakitan, A. M. (1998). Petroleum Industry and the Monetisation of the Nigerian Economy, Unpublished MSc Thesis submitted to the University of Calabar, Calabar.

[17] Randy Stringer,(2001) How important are the 'non-traditional' economic roles of agriculture in development? CENTRE FOR INTERNATIONAL ECONOMIC STUDIES, Discussion Paper No. 0118.

[18] Sunday A. Eko, et al (2013) Beyond Oil: Dual-Imperatives for Diversifying the Nigerian Economy, Journal of Management and Strategy Vol. 4, No. 3; 2013. 